\title{
Branding Serbia as a Tourist Destination on the Global Market
}

\author{
Ivan Paunović* \\ Received: October 2013 | Accepted: March 2014
}

\begin{abstract}
Destination branding has become one of the most popular contemporary topics, both among tourism practitioners and politicians, because there is strong evidence that strong national destination brand supports commercial brands in industries related to tourism. Therefore, factors that influence destination brand loyalty are of crucial importance for understanding and promoting the brand.

Building brand loyalty is not just about repeat buying, but also about building customers emotional attachment to the brand. Global growth and diversification of tourist markets has transformed destinations from "vacation industry" concept, to "industry of experience" concept.

The study performed statistical tests with a goal to analyze the factors influencing brand loyalty in Serbia: age, length of stay and daily spending. Additionally, sub-brand loyalty levels are presented (by major destinations inside Serbia, markets of origin and by major themes for travel) in order to identify groups of tourists that are more loyal, and the ones that are less loyal to the destination brand of Serbia. The study results and recommendations should be used as a contribution towards designing national and regional destination marketing strategies.
\end{abstract}

Key words: Motivation, consumer behavior, loyalty, destination branding, destination marketing

\section{Introduction}

Shifting tourist demand in the global market is reshaping destination offer globally. That is why destination branding is among the most popular contemporary topics, both among tourism practitioners and politicians. More specifically, all existing destination brands are concerned with re-visitation. All destinations ask themselves: How does a brand ensure that tourists keep coming back (Yeoman \& McMahon-Beattie, 2OII)?

There is strong evidence that strong national destination brand supports commercial brands in all industries related to tourism. Dolnicar et al. found that one of the 4 most important factors influencing behavioral loyalty of airline passengers is the fact that the airline is a national carrier (Dolnicar, Grabler, Grün, \& Kulnig, 2OII). Djordjevic confirms that strong

\footnotetext{
* PhD student at Singidunum University, Tosin bunar 16, 11080 Belgrade, Serbia, ivan.paunovic.12@singimail.rs
} 
country brand can provide commercial brands with a unique set of values and enable positioning on the international market (Djordjevic, 2008).

A number of authors confirms the importance of researching factors that influence destination brand loyalty (Huang \& Chiu, 2006; Roy, 2OII; Su, Cheng, \& Huang, 2OII). Hallberg noticed that building brand loyalty is not just about repeat buying, but also about building customers emotional attachment to the brand (Hallberg, 2004).

The study performed statistical tests with a goal to analyze the relations between different factors influencing brand loyalty in Serbia: age, length of stay and daily spending. Additionally, sub-brand loyalty levels are presented (by major destinations inside Serbia, markets of origin and by major themes for travel) in order to identify groups of tourists that are more loyal, and the ones that are less loyal to the destination brand of Serbia. The study results and recommendations should be used as a contribution towards designing national and regional destination marketing strategies.

\section{Review of the literature}

\section{Global growth and diversification of tourism markets}

Tourism has had a stable growth and continued diversification for over 60 years now, which was facilitated by new technology, especially the development of new communication and transportation technology. New technology allows us to communicate face to face to people from almost any point on earth, and to travel further while paying an ever less price for this services (UNWTO, 2OII). Cheap supply of energy resources, and particularly oil, has made mass transportation possible, first through introduction of jet passenger aircrafts, and more recently through low cost passenger airlines. However, according to the "Peak Oil" theory, when oil extraction reaches $50 \%$ of world resources, the production will fall, and this will have far reaching consequences for both transportation industry and tourism (Leigh, 2OII).

Diversification of the tourism market has shifted the focus from production (destination) based tourism to marketing based tourism. Consequently, understanding the tourism market is essential in today's competitive environment. UNWTO estimated there is around 200 country destinations, and even larger number of region destinations inside of those countries. All of these destinations participate at international tourism fairs, the most notable being the one in Berlin in London (UNWTO and ETC, 2OII). Each one of these large number of destinations is trying to understand their markets, and create, promote and sell tourism products. The diversification trend has led to the situation where landlocked countries are competing side to side with Sun, Sea and Sand destinations. As Elakovic noticed, mature destinations are witnessing transformation from "vacation industry", to "industry of experience". Tourists are not interested only in "baking in the sun", which is forced by the tour-operators. In contrast, modern tourists are looking for dynamic vacation, socializing, adventure, sport activities, etc. (Elakovic, 2006). Similarly, Swarbrooke noticed that green tourist is concerned with issues related to transport, wildlife, conservation, resources use, pollution, operational practices of tourism organizations, new buildings, and recreational activities. Green tourist is a subgroup of the green consumer. This trend reflects the rising social and political power of groups concerned with environmental issues and biodiversity conservation (global warming, animal welfare, wildlife conservation, organic food, pollution, and recycling of waste products) (Swarbrooke \& Horner, 2007). 


\section{Destination image and branding}

Consumers do not buy only physical characteristics of the product or service, but also a symbolic meaning, which means they engage emotionally. In similar way the humans have personality characteristics, brands can also have personality-like characteristics (Evans, Jamal, \& Foxall, 2006). There are different components of tourism brand, which influence the consumer decision-making process at different stages. Balakrishnan found that for creating a choice set in consumer mind, a destination should focus on tourist attractions, history or culture and the experience knowledge. For helping the consumer finalize a decision, destination should provide the information on destination accessibility, economic value, comfort (accommodation), communication and safety. Reinforcing the information on heritage, culture and people can also help consumers reach a decision to visit the destination (Balakrishnan, Nekhili, \& Lewis, 2OII). In that sense, Rodrigues, Correia, and Kozak, propose a multidisciplinary approach on destination image construct: I. Philosophical perspective which deals with theoretical foundation, 2. Psychological perspective which deals with image formation, and 3. Semiotics which deal with image interpretation (Rodrigues, Correia, \& Kozak, 2OII). Moon et al., found that sport events help enhancing the destination image. If we separate intangible event quality factors from tangible event quality factors on perception of event quality, intangible factors (Communication, Assurance, Credibility, Responsiveness, Reliability, and Security) are more important than tangible factors (Equipment, Ambience, and Design). The same is true for effect of event quality factors on destination image (Conative, Affective, and Cognitive) (Moon, Kim, Ko, Connaughton, \& Lee, 2OII).

Although destination brand can be promoted in many different ways, authors agree that sport events, movies, music events and architecture are an effective tools for destination branding. Kotler and Gertner noticed that entertainment industry and the media shape largely people's perceptions of places (Kotler \& Gertner, 2OII). Ooi presents the case of introducing FI races to Singapore, in a city that had a ban on sport races for 35 years. The public also had a concerns about introducing the FI, as it is a popular culture event, not adding uniqueness or refinement to the brand of Singapore. In 2008, the city hosted a first FI race, and the author emphasizes that one of the major effects of hosting an FI race is that adds to its glamour and popularity among wider audience. Numerous celebrities visit the event and media stories about it give it demonstrate that Singapore is glamorous, exciting and trendy city (Ooi, 2OII). Branding through movies is an often used promotional technique of many products and services, while tourist destinations (tourist brands, landscapes, soundscapes, etc.) are one of the products very often advertised through movies. As noted by Vagionis and Loumioti, tourism policy makers on all levels should prepare long-term strategies of utilization of cinematographic films, along with other promotional media. The strategy should incorporate recognizable tourist products that can reach, or already have reached the status of Iconic place/product. This products should have infrastructure and resources that can support the increasing numbers of visitors (Vagionis \& Loumioti, 2OII). Pratt notices that economic effects of film induced tourism are under researched, and presents the case of Pride and Prejudice movie map. A movie map marketing campaign was devised to coincide with the release of the 2005 Pride and Prejudice movie, based on the classical novel, written by Jane Austen. The study estimated that movie map promotional campaign generated over $€$ I million of income to the destination, with 8:I return on investment. The research quantified the incremental visitor expenditure spent in the region that was generated by the movie map marketing campaign (Pratt, 2OIO). McCarthy et al. present 3 cases of musical festivals in Australia, with different music genres: opera, Australian country music, and chamber 
music. The authors emphasize that regardless of the music genre, the sustainability of music festivals depends on the level of engagement of the local community. Moreover, the authors found evidence that the emphasis of government funding on tourism gains can undermine local networks, which are essential in communicating the local values (McCarthy, Moscardo, Murphy, \& Pearce, 2OIO). While architecture branding is usually associated with city destinations (Manic \& Backovic, 2OIO; Garaca, Jovanovic, \& Pejovic, 2OII), Medica et al investigated the possibility of architecture branding in the rural setting. Traditional architecture is part of cultural heritage in rural destinations of Istria in Croatia. The techniques used in traditional Istrian architecture are: patinating plaster using earth pigments, patinating wooden paneling, timber waxing, the use of old furniture, the production of simple furniture and household equipment using second-hand materials. All these techniques make up an authentic ambient which can offer more value to tourists and immersion into tradition local culture (Medica, Ruzic, \& Ruzic, 2OIO).

Yeoman and McMahon-Beattie notice that there is a strong empirical evidence that people openly agree that if a famous person endorses a product, they would be more likely to buy it (Yeoman \& McMahon-Beattie, 2OII). In fact, fifth of the UK population was found in 20O4, according to the Future foundation, to be more likely to buy a product if a famous person endorses it (Yeoman, 2008). However, Yeoman and Mc Mahon-Beattie emphasize that celebrity association is not a quick fix for a brand struggling with identity. Additionally, if the brand is not congruent with the celebrity who endorses it, it may have a detrimental impact on the brand (Yeoman \& McMahon-Beattie, 2OII).

Kotler and Gertner emphasize that brands allow marketers to identify and differentiate their product from their competitor, and they also incite beliefs, evoke emotions, and prompt behaviours (Kotler \& Gertner, 2OII). However, the challenges in the region of Balkans are similar to those described by Olins and Hildreth, when former European colonies, in the decades following 1945, changed several times their names, and in some cases territories. The list is long, and all of this countries tried to break away from their colonial past, through uncovering, discovering and inventing traditions. Authors conclude that contemporary nation branding is complex and multifaceted. The recent development saw the reemergence of city states like Dubai and Singapore, and development of shadowy super regions like the EU. The author sees the future of the EU nations in creation of European umbrella identity which is not overpowering, or all-consuming (Olins \& Hildreth, 2OII). Additionally, most Western Balkan countries also have to recover their destination brands from the war-zone image. Jovanovic emphasizes the importance of addressing the issue of war-zone image and subsequent reconciliation, and not trying to disregard them (Jovanovic, 2008). The case of rebranding Northern Ireland, presented by Gould, showcased that considerable effort is needed, from different types of stakeholders, to recreate the image of a post-conflict society. The Northern Ireland was invited to the Smithsonian Folk life Festival in Washington D.C. One year before the event, "Rediscover" brand was created as an umbrella identity for all individual stakeholders, website was launched, communications unit established, and a PR agency in Washington was employed. Also, the most senior civil servants and business leaders directly supported the event (Gould, 2OII). Wilson judged this rather big event to be a success, with an estimated audience of II2 million viewers in the US, and 386 press cuttings in the US and N. Ireland (Wilson, 2008). 


\section{Research design}

The research was designed to answer the following 9 Research questions:

- RQI: Is there a statistically significant correlation between age and daily spending of tourist in Serbia?

- RQ2: Is there a statistically significant correlation between age and daily spending of tourists in Serbia?

- RQ3: Is there a statistically significant correlation between age and brand loyalty of tourists in Serbia?

- RQ4: Is there a statistically significant correlation between daily spending and length of stay of tourists in Serbia?

- RQ5: Is there a statistically significant correlation between daily spending and brand loyalty of tourists in Serbia?

- RQ6: Is there a statistically significant correlation between length of stay and brand loyalty of tourists in Serbia?

- RQ7: What are brand loyalty levels to Serbia for major destinations inside Serbia?

- RQ8: What are brand loyalty levels to Serbia by region of origin?

- RQ9: What are brand loyalty levels to Serbia by main theme for travel?

The research was designed to answer the Research Questions I to 6 through utilizing the correlation analysis, and Research Questions 7-9, through descriptive statistics.

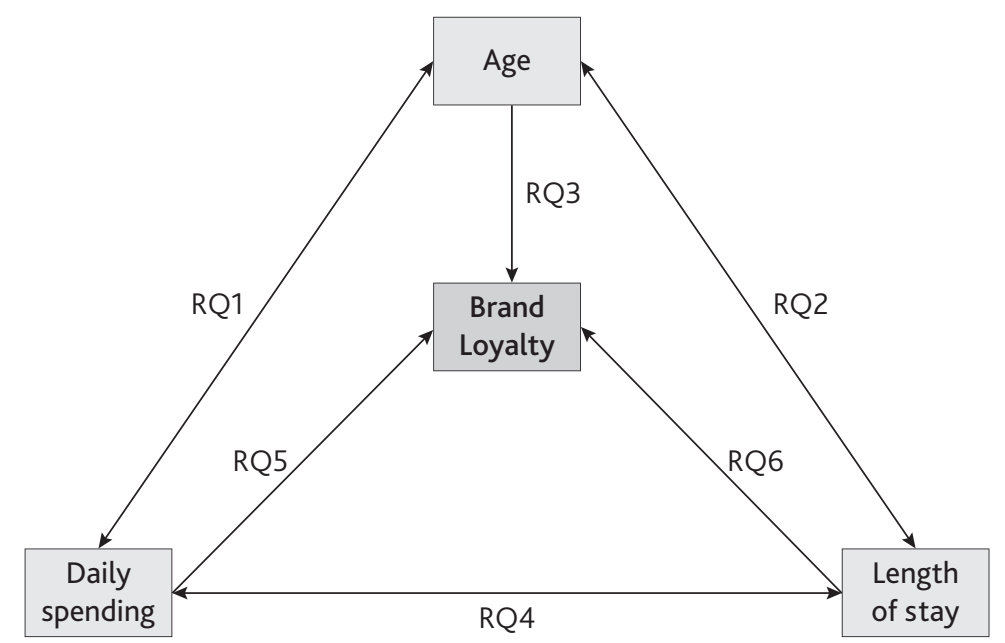

Figure1. Research design for Research Questions 1 to 6

\section{Research methodology}

The data was collected during Serbia Guest Survey 20II. This survey has been conducted as a component of the EU financed project: "Support to implementation of the National Strategy for Tourism". Only one portion of the data collected was used in the presented study. The objectives of the survey were to assess tourist profiles, core motives for travel, booking habits, expenditures, satisfaction and image perception of Serbia. The fieldwork was done only for 
the summer season: from July II 2OII to September 5 2OII. The data were processed through SPSS.

Table 1. The scales used in the research for age, length of stay and daily spending

\begin{tabular}{|c|c|c|c|c|c|c|c|c|c|c|c|c|c|c|}
\hline $\begin{array}{l}\text { Age } \\
\text { (years) }\end{array}$ & $14-18$ & $\begin{array}{l}19- \\
24\end{array}$ & $\begin{array}{l}25- \\
34\end{array}$ & $\begin{array}{l}35- \\
44\end{array}$ & $\begin{array}{l}45- \\
54\end{array}$ & $55-64$ & $\begin{array}{c}\text { Above } \\
65\end{array}$ & & & & & & & \\
\hline $\begin{array}{l}\text { Length of } \\
\text { stay (days) }\end{array}$ & Up to 3 & $4-7$ & $8-10$ & $\begin{array}{l}11- \\
15\end{array}$ & $\begin{array}{l}16- \\
30\end{array}$ & $\begin{array}{l}\text { More } \\
\text { than } 30\end{array}$ & & & & & & & & \\
\hline $\begin{array}{l}\text { Daily spend- } \\
\text { ing }(€)\end{array}$ & $\begin{array}{c}\text { No ex- } \\
\text { penditures }\end{array}$ & $\begin{array}{l}\text { Up } \\
\text { to } 5\end{array}$ & $6-10$ & $\begin{array}{l}11- \\
20\end{array}$ & $\begin{array}{l}21- \\
30\end{array}$ & $31-50$ & $51-70$ & $\begin{array}{l}71- \\
100\end{array}$ & $\begin{array}{l}101- \\
150\end{array}$ & $\begin{array}{l}151- \\
200\end{array}$ & $\begin{array}{l}201- \\
300\end{array}$ & $\begin{array}{l}301- \\
400\end{array}$ & $\begin{array}{l}401- \\
500\end{array}$ & $\begin{array}{c}\text { More } \\
\text { than } 500\end{array}$ \\
\hline
\end{tabular}

Brand loyalty was measured as an index consisting of 5 variables, with 6-point scale (I to 6):

- Recommending Serbia

- Attachment to Serbia

- How special is Serbia on the personal level

- Identification with Serbia

- Uniqueness of Serbia as a destination

Table 2. Sample size and regional distribution

\begin{tabular}{|l|r|r|}
\hline Destination & $\begin{array}{c}\text { The size of the sample (weighted } \\
\text { according to the official statistics) }\end{array}$ & \multicolumn{1}{|c|}{ Percentage } \\
\hline Belgrade & 300 & 14.42 \\
\hline Lower Danube & 30 & 2.36 \\
\hline Vrsac-South Banat & 125 & 7.88 \\
\hline Fruska gora & 100 & 7.80 \\
\hline Palic & 119 & 7.58 \\
\hline Novi Sad & 100 & 4.86 \\
\hline Stara Planina & 45 & 3.55 \\
\hline Nis & 106 & 7.44 \\
\hline Kopaonik & 180 & 14.08 \\
\hline Novi Pazar & 20 & 1.25 \\
\hline Zapadna Srbija/Zlatibor & 200 & 15.16 \\
\hline Divcibare/Valjevo & 130 & 10.09 \\
\hline Vrnjacka banja & 45 & 3.52 \\
\hline Total & 1500 & 100 \\
\hline
\end{tabular}

\section{Report of findings}

In order to test Research questions from I to 6, correlation analysis has been conducted in SPSS. Since level of significance is a messy topic regarding the correlation analysis (it can be misleading), it was excluded from the further analysis. Instead, the analysis focused on the Pearson correlation coefficient only, which was analyzed according to the following general rule: 
- Weak relationship (from o to O.30)

- Moderate relationship (from 0.30 to 0.70)

- Strong relationship (from 0.70 to I)

The results are as follows:

Table 3. Correlation analysis using Pearson Correlation in SPSS

\begin{tabular}{|c|c|c|c|c|c|}
\hline & & Age & Daily Spending & Length of Stay & Loyalty \\
\hline \multirow{3}{*}{ Age } & Pearson Correlation & 1 & -.275 & .218 & .342 \\
\hline & Sig. (2-tailed) & & .550 & .639 & .453 \\
\hline & $\mathrm{N}$ & 7 & 7 & 7 & 7 \\
\hline \multirow{3}{*}{ Daily Spending } & Pearson Correlation & -.275 & 1 & -.520 & -.870 \\
\hline & Sig. (2-tailed) & .550 & & .231 & .011 \\
\hline & $\mathrm{N}$ & 7 & 7 & 7 & 7 \\
\hline \multirow{3}{*}{ Length of Stay } & Pearson Correlation & .218 & -.520 & 1 & 674 \\
\hline & Sig. (2-tailed) & .639 & .231 & & .097 \\
\hline & $\mathrm{N}$ & 7 & 7 & 7 & 7 \\
\hline \multirow{3}{*}{ Loyalty } & Pearson Correlation & .342 & -.870 & 674 & 1 \\
\hline & Sig. (2-tailed) & .453 & .011 & .097 & \\
\hline & $\mathrm{N}$ & 7 & 7 & 7 & 7 \\
\hline
\end{tabular}

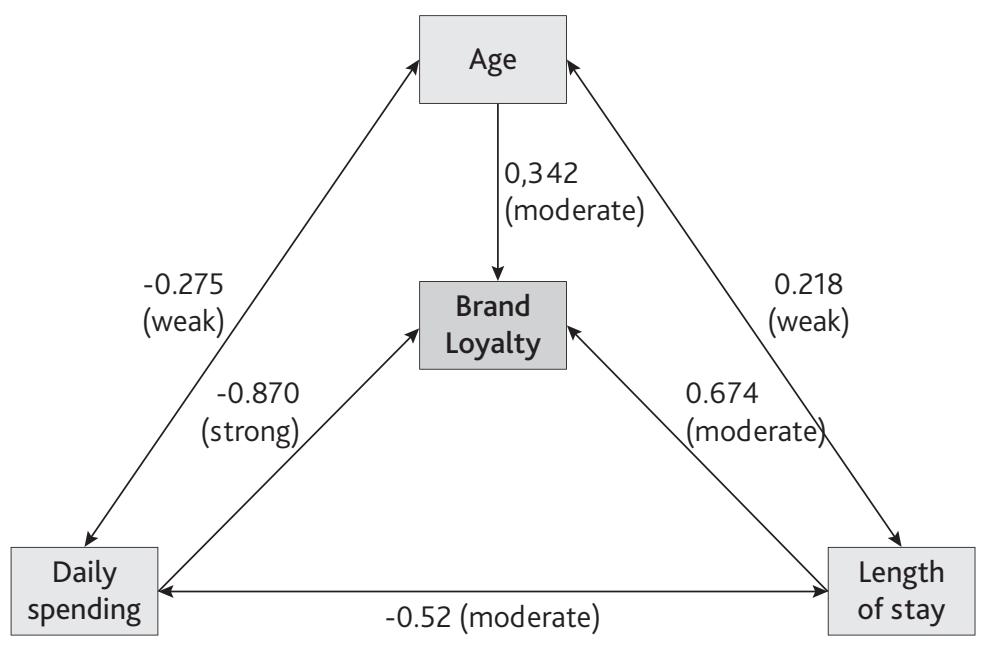

Figure 2. Correlations between the variables

In order to answer Research Question 7, descriptive statistics was used. Average brand loyalty for 5 brand attributes (recommendation, attachment, identification, personal attachment and uniqueness) for major destinations in Serbian tourism market is: Zlatibor (4.7I), Kopaonik (4.I7), Nis (3.93), Novi Sad (4.32), Belgrade (4.49). Average scores indicate different levels of brand loyalty which are a useful tool for defining competitive environment of local destinations in Serbia. Serbia, as an umbrella tourism brand, is strong as its local destination brands are strong. 
Table 4. 5 Brand attributes by major destinations in Serbian tourism

\begin{tabular}{|c|c|c|c|c|c|c|}
\hline Destinations & $\begin{array}{l}\text { Recommending } \\
\text { Serbia }\end{array}$ & $\begin{array}{l}\text { Attachment to } \\
\text { the brand }\end{array}$ & $\begin{array}{l}\text { How special is } \\
\text { Serbia on the } \\
\text { personal level }\end{array}$ & $\begin{array}{l}\text { Identification } \\
\text { with Serbia }\end{array}$ & $\begin{array}{l}\text { Uniqueness } \\
\text { of Serbia as a } \\
\text { destination }\end{array}$ & $\begin{array}{c}\text { Brand loyalty } \\
\text { (5 attributes } \\
\text { average) }\end{array}$ \\
\hline Belgrade & 5.46 & 4.48 & 4.40 & 4.22 & 3.91 & 4.49 \\
\hline Novi Sad & 5.76 & 4.26 & 4.30 & 4.00 & 3.30 & 4.32 \\
\hline Nis & 5.20 & 4.00 & 3.84 & 3.62 & 3.00 & 3.93 \\
\hline Kopaonik & 5.06 & 4.18 & 4.16 & 3.86 & 3.58 & 4.17 \\
\hline Zlatibor & 5.69 & 4.78 & 4.82 & 4.38 & 3.89 & 4.71 \\
\hline Total & 5.43 & 4.34 & 4.30 & 4.02 & 3.54 & 4.33 \\
\hline
\end{tabular}

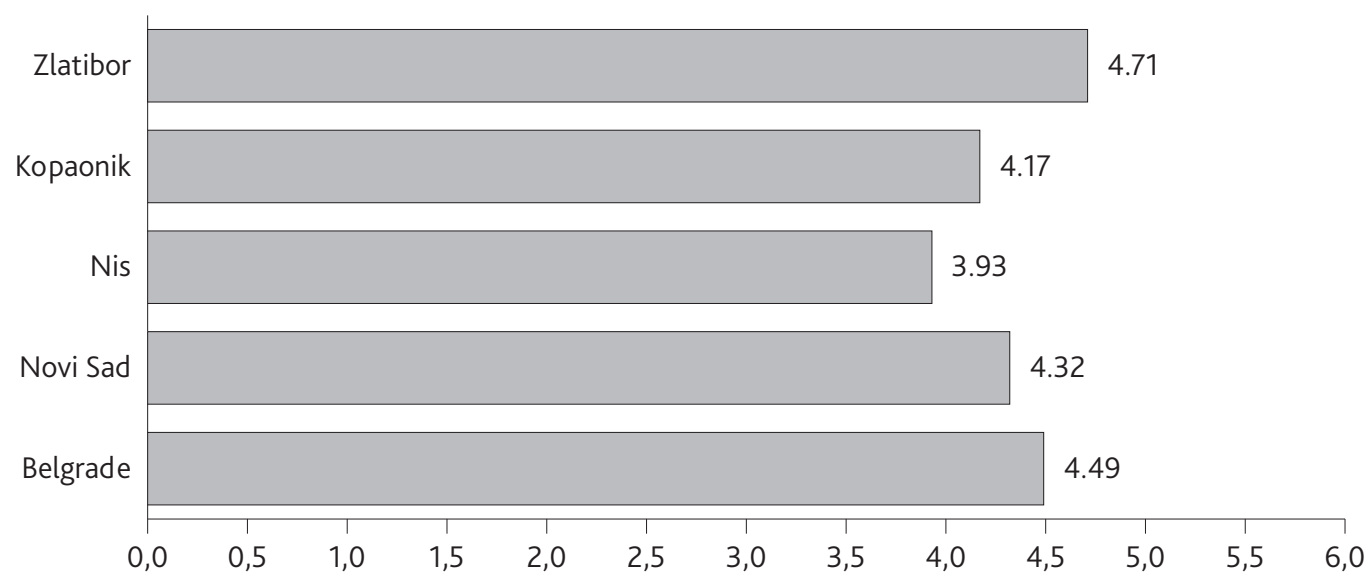

Figure 3. Brand loyalty by destination (scale 1-6)

In order to answer Research Question 8, descriptive statistics was used. Average brand loyalty score on 5 brand attributes (recommendation, attachment, identification, personal attachment, and uniqueness), by region of origin of tourists in Serbian tourism market is: Expatriate/Emigrant (4.6I), Ex-Yugoslavia (4.I5), Central-Eastern Europe (3.90), Western Europe and the rest of the world (3.92), Domestic (4.46). Emigrants or diaspora are persons who have a permanent residence abroad, but have had a permanent residence in Serbia before, or were born in Serbia, or have some other type of connection to Serbia.

Table 5. 5 Brand attributes by regions of origin in Serbian tourism

\begin{tabular}{|l|r|r|r|r|r|r|}
\hline Region of origin & \multicolumn{1}{|c|}{$\begin{array}{l}\text { Recommend- } \\
\text { ing Serbia }\end{array}$} & $\begin{array}{l}\text { Attachment to } \\
\text { the brand }\end{array}$ & $\begin{array}{l}\text { How special is } \\
\text { Serbia on the } \\
\text { personal level }\end{array}$ & $\begin{array}{c}\text { Identification } \\
\text { with Serbia }\end{array}$ & $\begin{array}{c}\text { Uniqueness } \\
\text { of Serbia as a } \\
\text { destination }\end{array}$ & $\begin{array}{c}\text { Brand loyalty } \\
\text { (5 attributes } \\
\text { average) }\end{array}$ \\
\hline Domestic & 5.42 & 4.50 & 4.24 & 4.44 & 3.72 & 3.16 \\
\hline $\begin{array}{l}\text { Western Europe and } \\
\text { the rest of the world }\end{array}$ & 5.28 & 3.83 & 3.46 & 3.46 & 3.92 \\
\hline $\begin{array}{l}\text { Central Eastern } \\
\text { European }\end{array}$ & 5.36 & 3.64 & 3.42 & 4.13 & 3.90 \\
\hline Ex-Yugoslavia & 5.40 & 4.12 & 3.82 & 4.67 & 3.30 & 3.94 \\
\hline Expatriate/Emigrant & 5.33 & 4.69 & 4.42 & 4.20 & 3.47 & 4.15 \\
\hline Total & 5.36 & 4.16 & 3.87 & & 4.21 \\
\hline
\end{tabular}




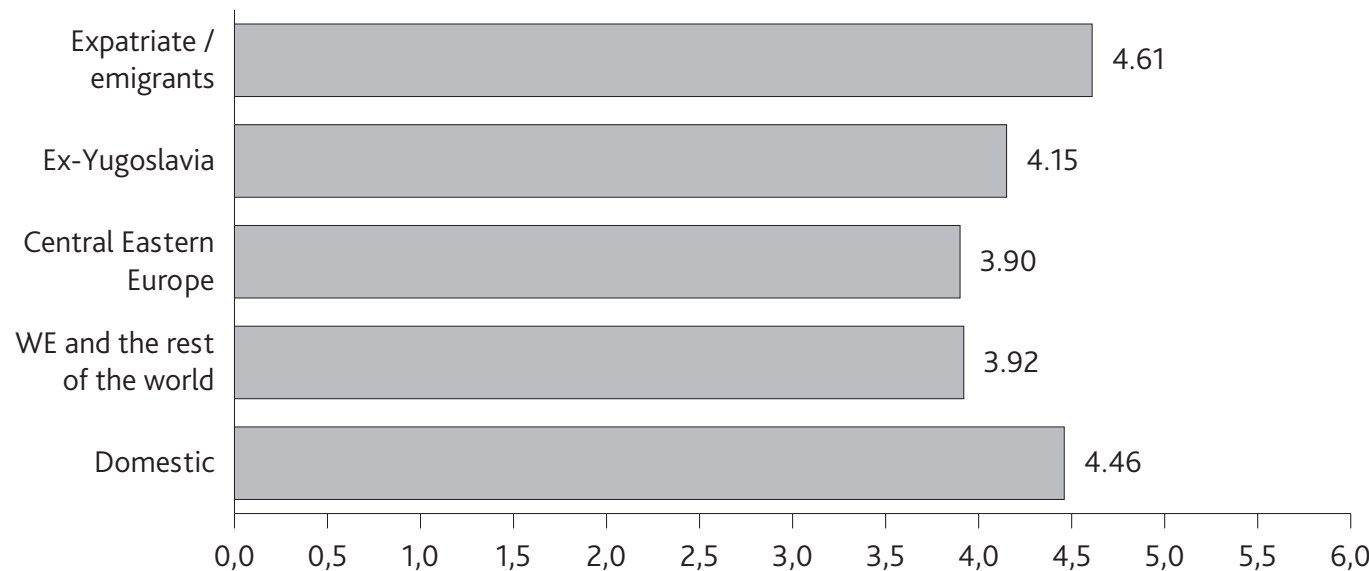

Figure 4. Brand loyalty by region/country of origin (scale 1-6)

In order to answer Research Question 9, descriptive statistics was used. Average brand loyalty score on 5 brand attributes (recommendation, attachment, identification, personal attachment, and uniqueness), by main theme for travel in Serbian tourism market is: Business (3.97), Health (4.9I), Sport \& Adventure (4.47), Culture (4.I6), Nature (4.38), Fun \& Entertainment (4.36), Pleasure (4.39).

Table 6. 5 Brand attributes by themes for travel in Serbian tourism

\begin{tabular}{|c|c|c|c|c|c|c|}
\hline $\begin{array}{l}\text { Main theme } \\
\text { for travel }\end{array}$ & $\begin{array}{l}\text { Recommend- } \\
\text { ing Serbia }\end{array}$ & $\begin{array}{l}\text { Attachment to } \\
\text { the brand }\end{array}$ & $\begin{array}{l}\text { How special is } \\
\text { Serbia on the } \\
\text { personal level }\end{array}$ & $\begin{array}{l}\text { Identification } \\
\text { with Serbia }\end{array}$ & $\begin{array}{l}\text { Uniqueness } \\
\text { of Serbia as a } \\
\text { destination }\end{array}$ & $\begin{array}{c}\text { Brand loyalty } \\
\text { (5 attributes } \\
\text { average) }\end{array}$ \\
\hline Pleasure & 5.42 & 4.41 & 4.32 & 4.17 & 3.63 & 4.39 \\
\hline $\begin{array}{l}\text { Fun and } \\
\text { entertainment }\end{array}$ & 5.48 & 4.31 & 4.35 & 4.05 & 3.59 & 4.36 \\
\hline Nature & 5.39 & 4.40 & 4.41 & 4.07 & 3.62 & 4.38 \\
\hline Culture & 5.33 & 4.07 & 4.22 & 3.93 & 3.24 & 4.16 \\
\hline Sport and Adventure & 5.22 & 4.36 & 4.40 & 4.45 & 3.93 & 4.47 \\
\hline Health & 5.56 & 4.98 & 4.99 & 4.67 & 4.35 & 4.91 \\
\hline Business & 5.03 & 4.04 & 3.82 & 3.79 & 3.16 & 3.97 \\
\hline Total & 7.49 & 6.11 & 6.10 & 5.83 & 5.10 & 6.13 \\
\hline
\end{tabular}




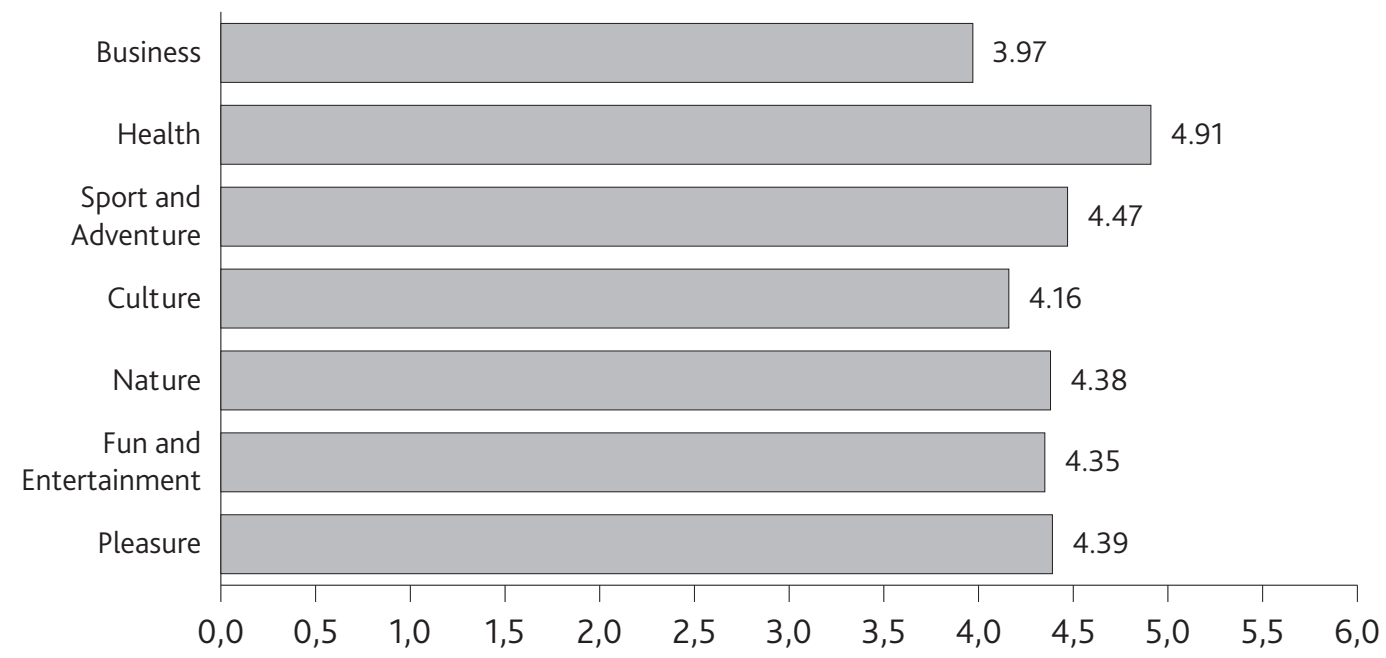

Figure 5. Brand loyalty by main theme for travel (score 1-6)

\section{Analysis of findings}

While age (0.342) and length of stay (0.674) influence moderately positively on the brand loyalty to destination Serbia, level of daily spending (-0.870) influences strongly negatively. This means that the older the tourists are, and the longer they stay on the destination, the more loyal they become to the destination Serbia. On the other hand, the higher is the level of daily spending on the destination, the lower is the loyalty to destination Serbia. The moderately negative correlation between daily spending and length of stay (-0.52), also points to the conclusion that the longer the tourists stay on the destination, the lower is the amount of their spending on the daily level.

Zlatibor has proved to be well ahead of all other destinations in Serbia regarding brand loyalty, followed by Belgrade and Novi Sad. Nis, on the other hand has the least loyal tourists.

The most loyal tourists are expatriates/emigrants, followed by domestic and ex-Yugoslavian tourists. The least loyal are tourists coming from Central-Eastern Europe.

The most loyal tourists are the ones traveling for health and sport and adventure, while the least loyal tourists are the ones traveling for business and culture.

The profile of the most loyal tourist to destination Serbia is the tourist that stays above average amount of days on the destination (above 7 days), has a below average level of daily spending on the destination (under 36 EUR), tends to be middle to older age (above 36 years), visits Zlatibor or Belgrade, is Expatriate/Emigrant, or domestic tourist, and travels for health or sport and adventure.

The profile of the least loyal tourist to destination Serbia is the tourist that stays below average amount of days on the destination (below 7 days), has an above average level of daily spending (over 36 EUR), tends to be of younger age (under 36 years), visits Nis, comes from Central-eastern Europe, and travels for business or culture. 


\section{Conclusions and recommendations}

The destination branding literature distinguishes branding of place and branding of nation as two separate concepts. This is especially important in the region of Western Balkans where a large number of local nation states exists, all of which are interconnected through an even larger number of ethnic minority groups, which all in effect blurs lines between place brand and nation brand. The future of the Western Balkans region will probably see the creation of the new European umbrella identity, and the reemergence of the city brands. This two new identities will diminish the importance of the nation states identities, which are presently dominant. In addition, rebranding strategies have to be considered, in order to recover destination brands from the images of the war-thorn past.

The study is a contribution towards designing tourism marketing strategy based on hard data. In that sense, the primary beneficiary of the study should be academic, private and public institutions dealing with marketing in the tourist markets. The data can also be used by museums and galleries, as one of the identified weaknesses of museums in Serbia is lack of modern managerial skills, and particularly marketing function. (Milic, Besermenji, \& Jovicic, 2OII) The research offers insights into brand loyalty of cultural tourists in relation to tourists travelling for other themes for travel.

Serbian tourism policy and marketing decision makers should take into account different factors influencing tourist behavior, as well as mutual interdependence between these factors. Separate marketing strategies should be devised for different groups of tourists, regarding main theme for travel. For Health tourists, which make the core loyalty base, there should be some form of loyalty program put in place. Culture and business tourists, while very valuable segments of the market, are the least loyal tourists, and considerable effort and resources will have to be invested in order to brand Serbia as business and cultural tourists destination. Additionally, research and promotional efforts of the NTOS (National Tourism Organization of Serbia) should focus on countries where a large Serbian diaspora (emigrants) exists, as the diaspora constitutes the core loyalty base of Serbian tourism. A repositioning and rebranding strategy should be devised to the markets of Central and Eastern Europe. Nis should consider rebranding in order to reposition its offer on the tourism market, while Zlatibor and Belgrade should expand its offer, and actively promote to new markets.

The survey was conducted during summer season only. In that sense, the data should be approached with caution. On the other hand, the samples were, weighted according to the official statistics in order to gain more reliable data.

\section{References}

Balakrishnan, M. S., Nekhili, R., \& Lewis, C. (2OII ). Destination brand components. International Journal Culture, Tourism and Hospitaity Research 5(I), 4-25.

Djordjevic, B. (2008). Corporate Strategic Branding: How Country And Corporate Brands Come Together. Ekonomski Anali 53(I77), 59-88.

Dolnicar, S., Grabler, K., Grün, B., \& Kulnig, A. (2OII). Key drivers of airline loyalty. Tourism Management, IO2O-IO26.

Elakovic, S. (2006). Sociology of free time and tourism. Belgrade: SPEKTRA.

Evans, M., Jamal, A., \& Foxall, G. (2006). Consumer behaviour. Chichester: John Wiley and Sons Ltd. 
Garaca, V., Jovanovic, G., \& Pejovic, L. (2OII). Petrovaradin Fortress (Novi Sad, Serbia): Tourism Spatial Planning and Design of The Upper Town for the Function of Cultural Tourism . Turizam I5(2), 65-76.

Gould, M. (2OII). Branding a post-conflict destination: Northern Ireland. In N. Morgan, A. Pritchard, \& R. Pride, Destination Brands: Managing Place Reputation (32I-333). Oxford: Elsevier.

Hallberg, G. (2004). Is Your Loyalty Program Really Building Loyalty? Why Increasing Emotional Attachment, Not Just Repeat Buying, Is Key to Maximizing Programme Success. Journal of Targeting, Measurement and Analysis of Marketing, 23I-34I.

Huang, H. H., \& Chiu, C. K. (2006 ). Exploring Customer Satisfaction, Trust and Destination Loyalty in Tourism. The Journal of American Academy of Business IO(I), I56-I59.

Jovanovic, D. (2008). Identity For Sale - Construction of a National Identity for the Needs of Tourism. Glasnik Etnografskog Instituta SANU 56 (I), IOI-II4.

Kotler, P., \& Gertner, D. (2OII). A place marketing and place branding perspective revisited. In N. Morgan, A. Pritchard, \& R. Pride, Destination Brands: Managing Place Reputation (33-53). Oxford: Elsevier.

Manic, Z., \& Backovic, V. (2OIO). Arhitektura Moderne u Fuknciji Promocije Beograda. Arhitektura i Urbanizam 30, 47-5I.

McCarthy, B., Moscardo, G., Murphy, L., \& Pearce, P. (2OIO). Music-tourism networks. In M. Kozak, J. Gnoth, \& L. Andreu, Advances in Tourism Destination Marketing (74-87). Abingdon: Routledge.

Medica, I., Ruzic, P., \& Ruzic, T. (2OIO). Architecture as a Tool for Branding in Rural Istrian Tourism Destination. Turizam, 78-86.

Milic, N., Besermenji, S., \& Jovicic, D. (2OII). Tourism Importance of museums in Vojvodina. Collection of papers-Faculty of Geography, University of Belgrade 59.

Moon, K. S., Kim, M., Ko, J. J., Connaughton, D. P., \& Lee, J. H. (2OII ). The influence of consumer's event quality perception on destination image. Managing Service Quality 2I(3), 287-303.

Olins, W., \& Hildreth, J. (2OII). Nation branding: Yesterday, today and tommorow. In N. Morgan, A. Pritchard, \& R. Pride, Destination Brands: Managing Place Reputation (55-66). Oxford: Elsevier.

Ooi, C.-S. (2OII). Branding ad the accreditation approach: Singapore. In N. Morgan, A. Pritchard, \& R. Pride, Destination Brands: Managing place reputation (I85-I96). Oxford: Elsevier.

Pratt, S. (2OIO). A movie map conversion study: A case study of Pride and Prejudice. In M. Kozak, J. Gnoth, \& L. Andreu, Advances in Tourism Destination Marketing (59-73). Abingdon: Routledge.

Rodrigues, A. I., Correia, A., \& Kozak, M. (2OII). A multidisciplinary approach on destination image construct. Tourismos 6(3), 93-IIO.

Roy, S. (2OII). Brand Measurement. SCMS Journal of Indian Management, II2-I22.

Su, H.-J., Cheng, K.-F., \& Huang, H. H. (2OII). Empirical study of destination loyalty and its antecedent: the perspective of place attachment. The Service Industries Journal 3I(I6), 272I2739.

Swarbrooke, J., \& Horner, S. (2007). Consumer Behaviour in Tourism, Second Edition. Oxford: Elsevier.

UNWTO and ETC. (2OII). Handbook on Tourism Product Development. Madrid: UNWTO (World Tourism Organization). 
UNWTO. (2OII). Policy and Practice for Global Tourism. Madrid: UNWTO (Word Tourism Organization).

Vagionis, N., \& Loumioti, M. (2OII ). Movies as a tool of modern tourist marketing. Touris$\operatorname{mos} 6(2), 353-362$.

Wilson, P. (2008). Northern Ireland at the Smithsonian. Report on Participation in the 4Ist Smithsonian Folklife Festival. Northern Ireland: Department for Culture, Arts and Leisure.

Yeoman, I. (2008). Tommorow's tourist. Oxford: Elsevier.

Yeoman, I., \& McMahon-Beattie. (2OII). The future challenge. In N. Morgan, A. Pritchard, \& R. Pride, Destination Brands: Managing Place Reputation (I69-I82). Oxford: Elsevier. 